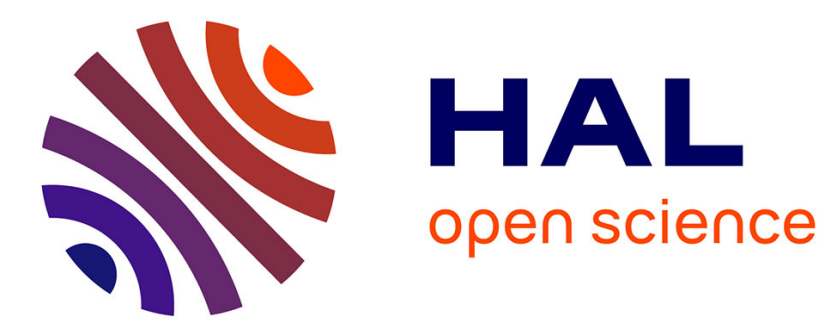

\title{
11 C-Labeling: Intracyclic Incorporation of Carbon-11 into Heterocycles
}

\author{
François Liger, Florence Cadarossanesaib, Thibaut Iecker, Christian \\ Tourvieille, Didier Le Bars, Thierry Billard
}

\section{- To cite this version:}

François Liger, Florence Cadarossanesaib, Thibaut Iecker, Christian Tourvieille, Didier Le Bars, et al.. 11 C-Labeling: Intracyclic Incorporation of Carbon-11 into Heterocycles. European Journal of Organic Chemistry, 2019, 2019 (41), pp.6968-6972. 10.1002/ejoc.201901386 . hal-02382036

\section{HAL Id: hal-02382036 \\ https://hal.science/hal-02382036}

Submitted on 7 Dec 2020

HAL is a multi-disciplinary open access archive for the deposit and dissemination of scientific research documents, whether they are published or not. The documents may come from teaching and research institutions in France or abroad, or from public or private research centers.
L'archive ouverte pluridisciplinaire HAL, est destinée au dépôt et à la diffusion de documents scientifiques de niveau recherche, publiés ou non, émanant des établissements d'enseignement et de recherche français ou étrangers, des laboratoires publics ou privés. 


\title{
${ }^{11} \mathrm{C}$ labeling: Intracyclic incorporation of carbon-11 into heterocycles.
}

\author{
François Liger, ${ }^{[a]}$ Florence Cadarossanesaib, ${ }^{[a]}$ Thibaut lecker, ${ }^{[a]}$ Christian Tourvieille, ${ }^{[a]}$ Didier Le \\ Bars, ${ }^{[a],[b]}$ and Thierry Billard ${ }^{*[a],[b]}$
}

\begin{abstract}
Labeling of heterocycles with carbon-11 is generally performed through peripheral functionalizations and more scarcely inside heterocyclic core. Such less common approach usually requires preliminary multi-step synthesis of reactive species. Herein, a cyclization reaction by direct use of cyclotron-produced $\left[{ }^{11} \mathrm{C}\right] \mathrm{CO}_{2}$ is described to obtain various heterocycles intracyclically labeled in only 10 minutes.
\end{abstract}

\section{Introduction}

Positron emission tomography (PET) is a non-invasive medical imaging technique used as diagnostic tool in several pathologies. ${ }^{[1]} \mathrm{PET}$ is also more and more applied in drug design, allowing in vivo quantitative biodistribution and pharmacokinetic studies. ${ }^{[2]}$ This method requires radiolabeling of molecules with a positron emitting radioisotope.$^{[3]}$ Among the most useful isotopes, fluorine-18 and carbon-11 are preferentially employed. Even if fluorine-18 is preferred due to its superior radioactive half-life (109 min for fluorine-18 vs $20 \mathrm{~min}$ for carbone-11), ${ }^{11} \mathrm{C}$-molecules are still predominantly used for research purposes. Indeed, it is easier to obtain radiolabeled equivalent of existing drugs by "isotopic replacement" of carbon atom.

The main strategy for compounds labeling is generally peripheral introduction of ${ }^{11} \mathrm{C}$-subtituents. ${ }^{[3 a}$, 4] Radiolabeling inside the molecules core, in particular of heterocyclic structures, has been scarcely described.

Few intracyclic labelings with carbon- 11 have been previously performed with various ${ }^{11} \mathrm{C}$-reagents: ${ }^{[5]} \quad\left[{ }^{11} \mathrm{C}\right]$ phosgene,,$^{[6]}$ $\left[{ }^{11} \mathrm{C}\right]$ formic acid or derivatives, ${ }^{[7]} \quad\left[{ }^{11} \mathrm{C}\right]$ formaldehyde, ${ }^{[8]}$ $\left[{ }^{11} \mathrm{C}\right]$ cyanide,${ }^{[9]}\left[{ }^{11} \mathrm{C}\right]$ thiocyanate,${ }^{110]}\left[{ }^{11} \mathrm{C}\right] \mathrm{CS}_{2}{ }^{[11]}$ or $\left[{ }^{11} \mathrm{C}\right] \mathrm{CO} .{ }^{[12]}$ However, all these reagents require their preliminary preparation, often in tedious conditions, which is time consuming. The starting material is generally $\left[{ }^{11} \mathrm{C}\right] \mathrm{CO}_{2}$ produced with a cyclotron by ${ }^{14} \mathrm{~N}(\mathrm{p}$, $\alpha)^{11} \mathrm{C}$ nuclear reaction. Consequently, direct use of cyclotronproduced $\left[{ }^{11} \mathrm{C}\right] \mathrm{CO}_{2}$ could be of interest to obtain intracyclic radiolabeled heterocycles. Nevertheless, because of low reactivity of $\mathrm{CO}_{2}$, this approach has so far been little investigated.

[a] F. Liger, F. Cadarossanesaib, T. lecker, C. Tourvieille, Dr. D. Le Bars, Prof. Dr. T. Billard

CERMEP-In vivo imaging

59 Bd Pinel, 69677 Lyon, France

E-mail: Thierry.billard@univ-lyon1.fr

www.fmi-lyon.fr

[b] Dr. D. Le Bars, Prof. Dr. T. Billard

Institute of Chemistry and Biochemistry (UMR CNRS 5246),

Univ Lyon, Université Lyon 1, CNRS, CPE, INSA

43 Bd du 11 novembre 1918, 69622 Villeurbanne, France

Supporting information for this article is given via a link at the end of the document.((Please delete this text if not appropriate))
A first approach has been described by an in situ formation of isocyanates. ${ }^{[13]}\left[{ }^{11} \mathrm{C}\right] \mathrm{CO}_{2}$ has been trapped by a diamine or an amino-alcohol in a first step, followed by a dehydration in a second step, mediated by $\mathrm{POCl}_{3}$. The resulting isocyanates were then cyclized to provide corresponding imidazolones or oxazolidinones. This method still requires two steps and appears limited in term of substrates scope. More recently, cyclic ureas were synthesized by cyclization of azidoamines with $\left[{ }^{11} \mathrm{C}\right] \mathrm{CO}_{2}$, mediated by phosphine. ${ }^{[14]}$ However, this method is limited to urea compounds. Furthermore, heteroaromatic compounds cannot be directly obtained following these strategies.

\section{Results and Discussion}

We have previously described direct ${ }^{11} \mathrm{C}$-methylation of amines through an in situ metal/carbene-mediated reduction of carbon dioxide. ${ }^{[15]}$ During this process, the intermediate formation of formamides has been demonstrated. Consequently, we supposed that a similar strategy applied to diamines could lead to cyclic compounds.

This hypothesis has been evaluated with 1,2-phenylenediamine (1a) as starting material to obtain the corresponding benzimidazole (2a) (Table 1 ).

Starting from the described conditions for methylation of amines (entry 1), we were delighted to observe the formation of the expected benzimidazole $\mathbf{2 a}$, with good radiochemical yields (entry 1). However, in this assay, $10 \mathrm{mg}$ of diamine $1 \mathrm{a}$ have been used. Generally, smaller amounts (ca. $20 \mu \mathrm{mol}$ ) of starting material are engaged in radiolabeling reactions. Unfortunately, by decreasing the diamine 1a quantity $(1.1 \mathrm{mg})$, to match with a more traditional amount, radiochemical yield also dramatically diminished (entry 2). By using a slight excess of $\mathrm{ZnCl}_{2}$ and $\operatorname{IPr}$ (1,3-Bis(2,6diisopropylphenyl)imidazol-2-ylidene), a satisfactory result was reobtained (entry 3). However, an excess of silane appeared to be necessary to observe the expected cyclization (entries 3-4).

Some similar cyclizations have also been described with nonradioactive $\mathrm{CO}_{2} \cdot{ }^{[16]}$ Described conditions did not use any metal catalysts with a reaction time of $24 \mathrm{~h}$. Nevertheless, in our case the use of $\mathrm{ZnCl}_{2}$ appeared to be crucial to observe cyclization in a reaction time of only 20 min, more consistent with carbon-11 half-life (entry 5). The metal certainly contributes to accelerate reaction so fitting with the short time imposed by radioactive decay. 
Table 1. Cyclization reaction with $1 \mathrm{a}$ and $\left[{ }^{11} \mathrm{C}^{\mathrm{C}} \mathrm{CO}_{2}\right.$.

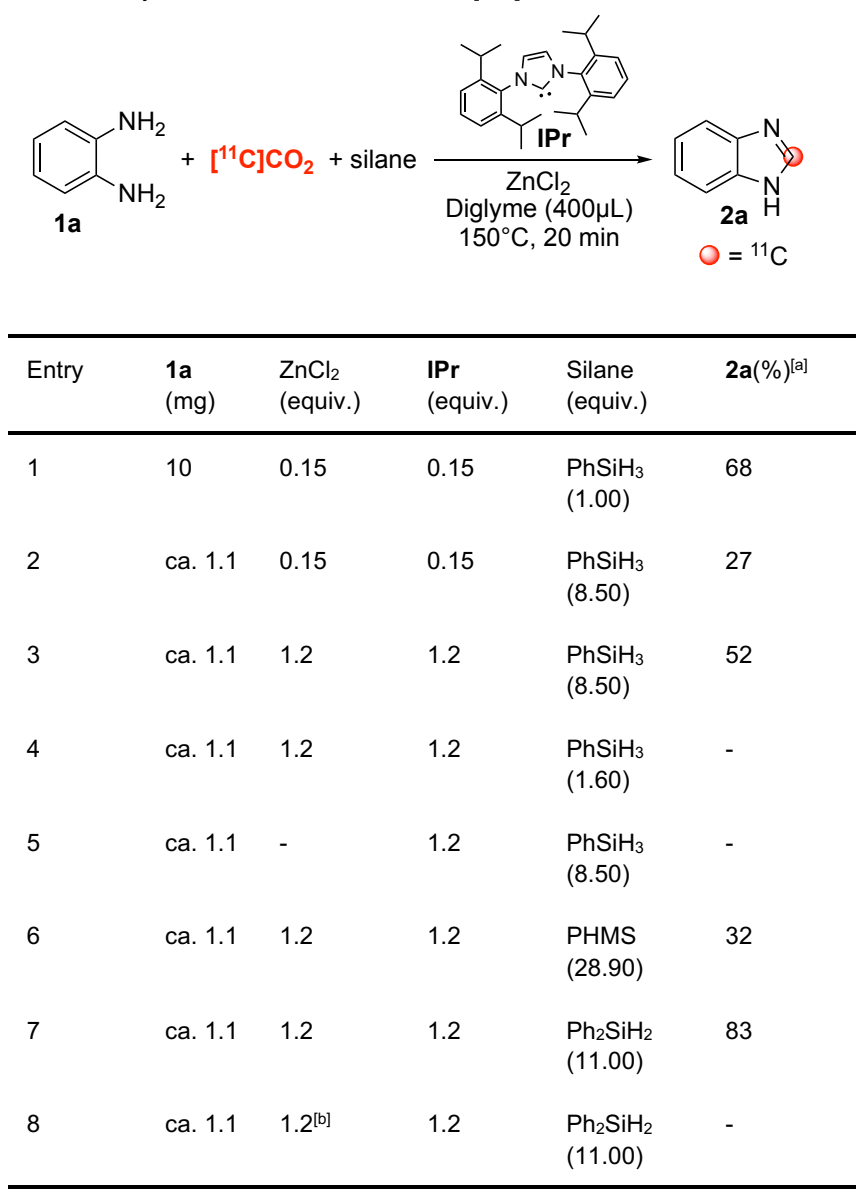

[a] Radiochemical yields (RCY) were estimated from trapped $\left[{ }^{11} \mathrm{C}\right] \mathrm{CO}_{2}$ within the reactor and are decay-corrected from end of $\left[{ }^{11} \mathrm{C}\right] \mathrm{CO}_{2}$ trapping inside reactor. [b] with $\mathrm{FeCl}_{3}$ instead of $\mathrm{ZnCl}_{2}$.

With $\mathrm{PhSiH}_{3}$ as reducing agent, the cyclization reaction is in competition with methylation of amino groups which can proceed in similar conditions. ${ }^{[15]}$ Indeed, some side-products arising from this methylation competitive reaction were also observed. To circumvent this drawback, less reducing silanes have been envisaged. If only low yields were obtained with PMHS (Poly(methylhydrosiloxane)), a higher and very good radiochemical yield was observed with $\mathrm{Ph}_{2} \mathrm{SiH}_{2}$ (entries 6-7). In this case, no methylation of amines was detected. Finally, $\mathrm{FeCl}_{3}$ has also been envisaged as catalyst but without any success (entry 8)

Even if a reaction time of $20 \mathrm{~min}$ is compatible with carbon-11 radiolabeling, shorter durations are generally expected. Consequently, with optimal conditions (entry 7), reaction time was reduced to $10 \mathrm{~min}$. An important decrease of radiochemical yield has been observed (Table 2, entries 1-2). Microwave activation was deleterious for the reaction, as already observed in the previously described radiomethylation reactions (entry 3). ${ }^{[15]}$ Doubling catalysts amounts did not bring significant improvement (entry 4). In contrast, an increase of concentration of precursor $\mathbf{1 a}$, associated with a decrease of reaction volume, brought positive effects and excellent radiochemical yields were observed (entries 5-7). By switching from $200 \mu \mathrm{L}$ to $100 \mu \mathrm{L}$, no significant improvement was observed. An attempt to reduce reaction time to $5 \mathrm{~min}$ led only to a medium result (entry 8 ). In view of these results, a volume of $200 \mu \mathrm{L}$ will be generally preferred for further investigations, to avoid potential solubility problems.

Table 2. Effect of reaction time and solvent volume ${ }^{[a]}$

\begin{tabular}{llll}
\hline Entry & Reaction time $(\mathrm{min})$ & Diglyme volume $(\mu \mathrm{L})$ & $\mathbf{2 a}(\%)^{[\mathrm{b}]}$ \\
\hline 1 & 20 & 400 & 83 \\
2 & 10 & 400 & 25 \\
3 & $10^{[\mathrm{c}]}$ & 400 & 1 \\
4 & $10^{[\mathrm{d}]}$ & 400 & 38 \\
5 & 10 & 300 & 66 \\
6 & 10 & 200 & 87 \\
7 & 10 & 100 & 90 \\
8 & 5 & 100 & 48 \\
\hline
\end{tabular}

[a] Conditions: 1a (1.1-2.2 mg), $\mathrm{ZnCl}_{2}$ (1.2 equiv.), IPr (1.2 equiv.), $\mathrm{Ph}_{2} \mathrm{SiH}_{2}$ (11 equiv.), diglyme, $150^{\circ} \mathrm{C}, 10 \mathrm{~min}$ ). [b] Radiochemical yields (RCY) were estimated from trapped $\left[{ }^{11} \mathrm{C}\right] \mathrm{CO}_{2}$ within the reactor and are decay-corrected from end of $\left[{ }^{11} \mathrm{C}\right] \mathrm{CO}_{2}$ trapping inside reactor. [c] under microwave irradiation (100 W). [d] $\mathrm{ZnCl}_{2}$ (2.4 equiv.), IPr (2.4 equiv.).

In these optimal conditions, molar activity of produced benzimidazole $2 \mathrm{a}$ was around $18 \mathrm{GBq} / \mu \mathrm{mol}$. To study the scope of this radiolabeling, various aromatic diamines were then studied (Scheme 1).

Various benzimidazoles were obtained with, in general, satisfactory to good radiochemical yields. Substitution onto nitrogen atom does not significantly influence the obtained results (2a-c). Whatever the electronic character (electron withdrawing or donor) of aromatic substituents, similar yields were observed (2af). However, slightly lower yields were observed with $\mathbf{2 g}$ and $\mathbf{2 h}$, maybe due to a competitive coordination of $\mathrm{ZnCl}_{2}$ catalyst by the carbonyl function $(\mathbf{2 g})$ or the nitrogen atom of the pyridine core $(2 \mathrm{~h})$. Interestingly, reaction is compatible with functional groups such as ketone $(\mathbf{2 g})$, ester $(\mathbf{2 e})$ or bromine $(\mathbf{2 d})$. In particular, no reduction side-products were detected.

To extend this radiolabeling methodology, 6-membered rings have been also studied. Thus, perimidine $\mathbf{2} \mathbf{i}$ was obtained with similar good yields compared to benzimidazoles. More interestingly, quinazolinone $\mathbf{2} \mathbf{j}$ was also synthesized starting from corresponding 2-aminobenzamide. Because of the weakest nucleophilicity of amide group, the expected cyclic product was formed with only a medium radiochemical yield. However, a good result was achieved by doubling reaction time to $20 \mathrm{~min}$. By decreasing solvent volume to $100 \mu \mathrm{L}$, a better yield was also observed in $10 \mathrm{~min}$. 
<smiles>[R]NC1=C(N)CCC1</smiles>

$89 \%(n=2)$<smiles>c1cnc2[nH]cnc2c1</smiles>

$2 \mathrm{~h}$

$54 \%(n=3)$<smiles>Cn1cnc2ccccc21</smiles>

2b

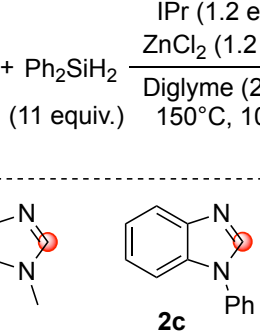<smiles>COc1cc2nc[nH]c2cc1OC</smiles>

$80 \%(n=2)$
$52 \%(n=2)$<smiles>O=C(c1ccccc1)c1ccc2[nH]cnc2c1</smiles><smiles>Brc1ccc2[nH]cnc2c1</smiles>

2d $74 \%(n=2)$<smiles></smiles>
$83 \%(n=3)$

Scheme 1. Cyclizations of aromatic diamines with $\left[{ }^{11} \mathrm{C}\right] \mathrm{CO}_{2}$. Radiochemical yields are mean values and were estimated from trapped $\left[{ }^{11} \mathrm{C}\right] \mathrm{CO}_{2}$ within the reactor and are decay-corrected from end of $\left[{ }^{11} \mathrm{C}\right] \mathrm{CO}_{2}$ trapping inside reactor. [a] reaction time $=20 \mathrm{~min}$. [b] diglyme volume $=100 \mu \mathrm{L}$

If benzimidazoles represent privileged structure in medicinal chemistry and drugs, ${ }^{[17]}$ benzothiazoles are also important heterocyclic compounds in drug design and pharmaceutical agents. ${ }^{[18]}$ This heterocycle is also used in radiotracers development, as illustrated by $\beta$-amyloid radioligand $\left[{ }^{11} \mathrm{C}\right] \mathrm{PIB} .{ }^{[19]}$ Consequently, our method was extended to aminobenzenethiols (3) to obtain, for the first time, intracyclically ${ }^{11} \mathrm{C}$-labeled benzothiazoles 4 (Scheme 2).

With optimal conditions used for benzimidazoles, only modest radiochemical yield was observed (4a). As demonstrated previously (Scheme $1 ; \mathbf{2} \mathbf{j})$, by decreasing solvent volume $(100 \mu \mathrm{L}$ instead of $200 \mu \mathrm{L}$ ), a better result is obtained. Nevertheless, in general, radiochemical yields remain modest, but suitable for workable radiolabelings.

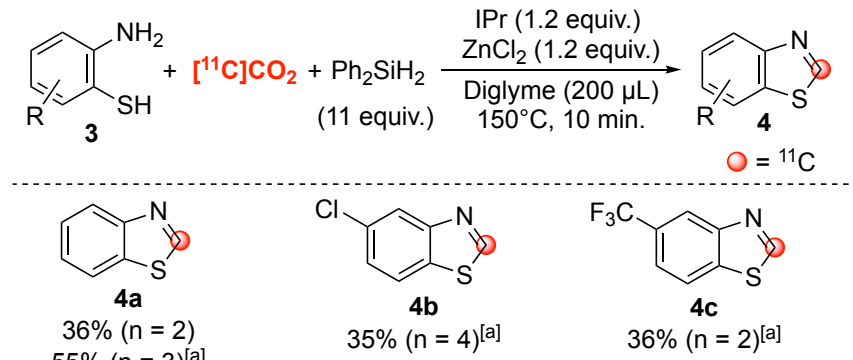

$55 \%(n=3)^{[a]}$

Scheme 2. Cyclizations of aminobenzenethiols with $\left[{ }^{11} \mathrm{C}\right] \mathrm{CO}_{2}$. Radiochemical yields are mean values and were estimated from trapped $\left[{ }^{11} \mathrm{C}\right] \mathrm{CO}_{2}$ within the reactor and are decay-corrected from end of $\left[{ }^{11} \mathrm{C}\right] \mathrm{CO}_{2}$ trapping inside reactor. [a] diglyme volume $=100 \mu \mathrm{L}$

This one-step, late stage, intracyclic labeling has been applied to the first ${ }^{11} \mathrm{C}$-labeling of theophylline $\operatorname{drug}^{[20]}(\mathbf{2 k})$, with intracyclic incorporation of radioisotope (Scheme 3 ).

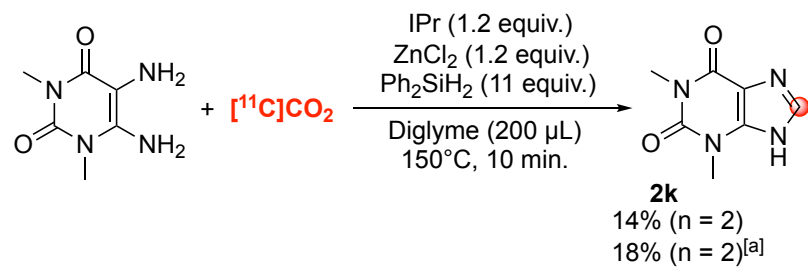

Scheme 3. Intracyclic labelling of theophylline. Radiochemical yields are mean values and were estimated from trapped $\left[{ }^{11} \mathrm{C}\right] \mathrm{CO}_{2}$ within the reactor and are decay-corrected from end of $\left[{ }^{11} \mathrm{C}_{\mathrm{CO}_{2}}\right.$ trapping inside reactor. [a] diglyme volume $=100 \mu \mathrm{L}$

$\left[{ }^{11} \mathrm{C}\right]$ Theophylline was obtained in a modest radiochemical yield. However, in view of the low reactivity of the starting diamine, the result remains quite satisfactory and demonstrates the usefulness of this method to label elaborated molecules.

During these previous investigations, some reproducibility issues were observed with a batch of IPr. Despite various analyses of the different batches of IPr, we have not succeeded to determine the reasons of such issues. Consequently, to try to circumvent such potential drawback, a preliminary preparation of $\mathbf{I P r}$ solutions in diglyme, just before use, was envisaged (Scheme 4). In comparison to commercial IPr, similar results were observed with benzimidazole or benzothiazole. This use of home-made solution of IPr constitutes a valuable alternative to potential reproducibility issue and we warmly recommend this simple to implement solution to avoid some disappointments during radiolabelings.

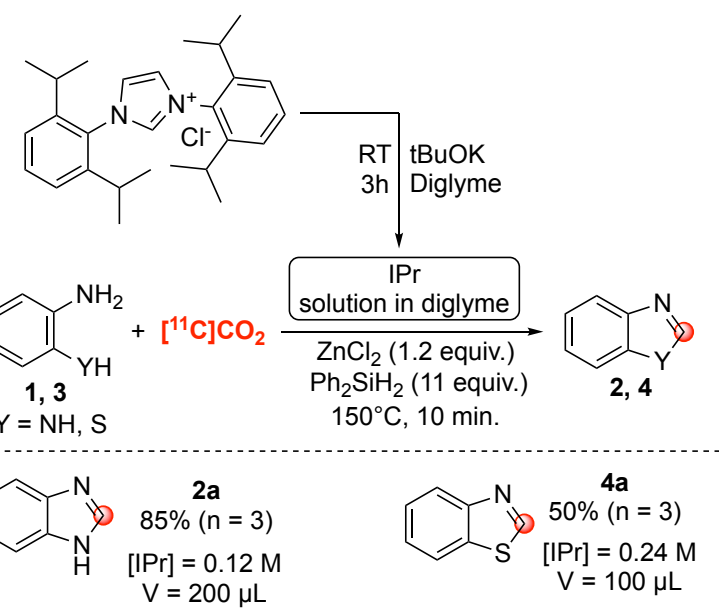

Scheme 4. Cyclization reactions with home-made solution of $\mathrm{IPr}$. Radiochemical yields are mean values and were estimated from trapped $\left[{ }^{11} \mathrm{C}\right] \mathrm{CO}_{2}$ within the reactor and are decay-corrected from end of $\left[{ }^{11} \mathrm{C}^{-} \mathrm{CO}_{2}\right.$ trapping inside reactor.

Finally, in order to demonstrate the effective productivity of this new radiolabeling approach, a full radiosynthesis, with HPLC 
purification, was performed with perimidine 2i (Scheme 5). Noteworthy, a home-made solution of IPr was preferred.
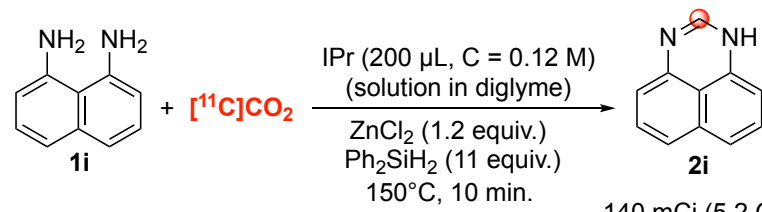

$140 \mathrm{mCi}(5.2 \mathrm{GBq})$ $\mathrm{RCY}=75 \%(\mathrm{n}=3)$ (overall time: $33 \mathrm{~min}$ )

Scheme 5. Production of perimidine $\mathbf{2} \mathbf{i}$. The RCY value is mean value and was estimated from trapped $\left[{ }^{11} \mathrm{C}\right] \mathrm{CO}_{2}$ within the reactor and are decay-corrected from end of $\left[{ }^{11} \mathrm{C}\right] \mathrm{CO}_{2}$ trapping inside reactor.

A good radioactive quantity $(140 \mathrm{mCi}, 5.2 \mathrm{GBq})$ of $\left[{ }^{11} \mathrm{C}\right]$ perimidine (2i) was produced with a high radiochemical yield $(\mathrm{RCY}=75 \%)$ and with a good radiochemical and chemical purity. This result is very encouraging and demonstrates the usefulness of this original radiolabeling method to produce radiotracers.

\section{Conclusions}

To conclude, cyclization reactions by direct use of cyclotronproduced $\left[{ }^{11} \mathrm{C}\right] \mathrm{CO}_{2}$ were described to obtain in a late stage and one-pot process, heterocyclic and heteroaromatic compounds intracyclically labeled with carbon- 11 . This strategy constitutes a proof of concept about direct use of $\left[{ }^{11} \mathrm{C}\right] \mathrm{CO}_{2}$ in "radiocyclization" reactions and should open the way to new developments concerning radiolabeling of heterocyclic molecules.

\section{Experimental Section}

Synthesis of $\left[{ }^{11} \mathrm{C}\right]$ perimidine (2i): $200 \mu \mathrm{L}$ of freshly prepared $\mathrm{IPr}$ solution in diglyme $(24 \mu \mathrm{mol}, 1.2 \mathrm{eq})$ was added to a $1 \mathrm{~mL}$ vial containing $3.15 \mathrm{mg}$ of 1,8-diaminonaphtalene $(20 \mu \mathrm{mol}, 1 \mathrm{eq})$. The resulting solution was sonicated for $2 \mathrm{~min}$ and transferred to a $1.1 \mathrm{~mL}$ conical vial pre-charged with $3.35 \mathrm{mg}$ of zinc chloride $(24.2 \mu \mathrm{mol}, 1.21 \mathrm{eq})$. After addition of $40 \mu \mathrm{L}$ of diphenylsilane $(0.215 \mathrm{mmol}, 11 \mathrm{eq})$, the vial was sealed and placed into the automated synthesis module $10 \mathrm{~min}$ before end of bombardment. When the desired level of radioactivity was reached in cyclotron (nearly $3000 \mathrm{mCi}-111 \mathrm{GBq}$ ), reaction with $\left[{ }^{11} \mathrm{C}\right] \mathrm{CO}_{2}$ proceeded according previous general procedure (see $\mathrm{SI}$ ). After $10 \mathrm{~min}$ of heating at $150^{\circ} \mathrm{C}$, the reaction vial was cooled at $20^{\circ} \mathrm{C}$ for 2.5 minutes. Then, $2 \times 100 \mu \mathrm{L}$ of $\mathrm{MeOH}$ were sequentially added to the reaction mixture (30 seconds apart) and after further 20 seconds, the whole content of the reaction vial was loaded into a $3 \mathrm{~mL}$ HPLC loop. $700 \mu \mathrm{L}$ of additional $\mathrm{MeOH}$ were used for rinsing the reaction vial and loaded into the HPLC loop before injection on semipreparative HPLC column (Macherey-Nagel Nucleodur C18 HTec column $(10 \mu \mathrm{m}, 10 \times 250 \mathrm{~mm})$. HPLC purification was conducted at $3 \mathrm{~mL} / \mathrm{min}$ with acetate buffer $\mathrm{pH} 5.2 / \mathrm{MeCN}$ (55/45) as mobile phase. Radioactive and UV monitoring at $254 \mathrm{~nm}$ allowed the collection of $346-386 \mathrm{mCi}(12.8-14.3$ $\mathrm{GBq}$, decay-corrected) of purified $1 \mathrm{H}-\left[{ }^{11} \mathrm{C}\right]$ Perimidine $2 \mathbf{i}$. Retention time was 8 minutes. Radiochemical yields were ranging from 70 to $80 \%$ decaycorrected.

\section{Acknowledgements ((optional))}

This work was supported by European Union (EU) through the project Radiochemistry for Molecular Imaging (project number EU FP7-PEOPLE-2012-ITN-RADIOMI). Frédéric Bonnefoi (CERMEP - in vivo imaging) is acknowledged for his technical assistance. The authors wish to thank the Centre National de la Recherche Scientifique (CNRS), Institut national de la santé et de la recherche médicale (INSERM) and University of Lyon 1 for financial support.

\section{Keywords: Carbon-11 • Heterocycles • Radiochemistry •} Radiolabeling $\bullet$ Positron emission tomography

[1] a) W. Cai, Mol. Pharm. 2014, 11, 3773-3776; b) G. B. Saha, Basics of PET Imaging: Physics, Chemistry, and Regulations, Springer New York, 2010; c) L. Zimmer, A. Luxen, Neuroimage 2012, 61, 363-370; d) S. M. Ametamey, M. Honer, P. A. Schubiger, Chem. Rev. 2008, 108, 15011516

[2] a) R. Chakravarty, H. Hong, W. Cai, Mol. Pharm. 2014, 11, 3777-3797 b) C. C. Wagner, O. Langer, Adv. Drug Del. Rev. 2011, 63, 539-546; c) J. K. Willmann, N. Van Bruggen, L. M. Dinkelborg, S. S. Gambhir, Nat. Rev. Drug Discov. 2008, 7, 591-607; d) M. Schou, K. Varnäs, Clin. Transl. Imaging 2017, 1-8; e) A. Testa, M. Zanda, C. S. Elmore, P. Sharma, Mol. Pharm. 2015, 12, 2203-2216.

[3] a) X. Deng, J. Rong, L. Wang, N. Vasdev, L. Zhang, L. Josephson, S. H. Liang, Angew. Chem. Int. Ed. 2019, 58, 2580-2605; b) P. W. Miller, N. J. Long, R. Vilar, A. D. Gee, Angew. Chem. Int. Ed. 2008, 47, 8998-9033; c) Z. Li, P. S. Conti, Adv. Drug Del. Rev. 2010, 62, 1031-1051.

[4] a) K. Dahl, C. Halldin, M. Schou, Clin. Transl. Imaging 2017, 5, 275-289 b) C. Taddei, A. D. Gee, J. Labelled Compd. Radiopharm. 2018, 61, $237-$ 251.

[5] a) B. H. Rotstein, S. H. Liang, M. S. Placzek, J. M. Hooker, A. D. Gee, F. Dolle, A. A. Wilson, N. Vasdev, Chem. Soc. Rev. 2016, 45, 4708-4726; b) A. Del Vecchio, G. Destro, F. Taran, D. Audisio, J. Labelled Compd. Radiopharm. 2018, 61, 988-1007.

[6] a) G. D. Brown, S. K. Luthra, C. S. Brock, M. F. G. Stevens, P. M. Price F. Brady, J. Med. Chem. 2002, 45, 5448-5457; b) F. Brady, S. K. Luthra, H.-J. Tochon-Danguy, C. J. Steel, S. L. Waters, M. J. Kensett, P. Landais, F. Shah, K. A. Jaeggi, A. Drake, J. C. Clark, V. W. Pike, Int. J. Rad. Appl. Instrum. A. 1991, 42, 621-628; c) C. Boullais, C. Crouzel, A. Syrota, J. Labelled Compd. Radiopharm. 1986, 23, 565-567; d) G. A. Brinkman, I. Hass-Lisewska, J. T. Veenboer, L. Lindner, Int. J. Appl. Radiat. Isot. 1978, 29, 701-702; e) C. Crouzel, G. Mestelan, E. Kraus, J. M. Lecomte, D. Comar, Int. J. Appl. Radiat. Isot. 1980, 31, 545-548; f) D. Roeda, G. Westera, Int. J. Appl. Radiat. Isot. 1981, 32, 843-845; g) M. Berridge, D. Comar, C. Crouzel, Int. J. Appl. Radiat. Isot. 1983, 34, 1657-1658; h) K. Yashio, Y. Katayama, T. Takashima, N. Ishiguro, H. Doi, M. Suzuki, Y. Wada, I. Tamai, Y. Watanabe, Bioorg. Med. Chem. Lett. 2012, 22, 115119; i) M. Berridge, D. Comar, C. Crouzel, J. C. Baron, J. Labelled Compd. Radiopharm. 1983, 20, 73-78; j) D. Roeda, B. Tavitian, C. Coulon, F. David, F. Dolle, C. Fuseau, A. Jobert, C. Crouzel, Bioorg. Med Chem. 1997, 5, 397-403; k) K.-I. Seki, K.-I. Nishijima, K. Sanoki, Y. Kuge M. Takahashi, H. Akizawa, N. Tamaki, L. I. Wiebe, K. Ohkura, Heterocycles 2009, 77, 1307-1321; I) Y. Takada, M. Ogawa, H. Suzuki, T. Fukumura, Appl. Radiat. Isot. 2010, 68, 1715-1720; m) G. Roger, F. Dolle, B. De Bruin, X. Liu, L. Besret, Y. Bramoulle, C. Coulon, M. Ottaviani, M. Bottlaender, H. Valette, M. Kassiou, Bioorg. Med. Chem. 2004, 12, 3229-3237; n) F. Dolle, Y. Bramoulle, F. Hinnen, S. Demphel, P. George, M. Bottlaender, J. Labelled Compd. Radiopharm. 2003, 46, 783-792; o) C. J. Steel, F. Brady, S. K. Luthra, G. Brown, I. Khan, K. G. Poole, A. Sergis, T. Jones, P. M. Price, Appl. Radiat. Isot. 1999, 51, 377 388; p) M. Berridge, D. Comar, D. Roeda, A. Syrota, Int. J. Appl. Radiat. Isot. 1982, 33, 647-651; q) D. Roeda, C. Crouzel, B. Van Zanten Radiochem. Radioanal. Lett. 1978, 33, 175-178; r) P. Landais, C. Crouzel, Appl. Radiat. Isot. 1987, 38, 297-300; s) M. Ogawa, Y. Takada H. Suzuki, K. Nemoto, T. Fukumura, Nucl. Med. Biol. 2010, 37, 73-76; t) Y. Bramoulle, D. Roeda, F. Dolle, Tetrahedron Lett. 2010, 51, 313-316; 
u) S. Bernard, C. Fuseau, L. Schmid, R. Milcent, C. Crouzel, Eur. J. Nucl. Med. 1996, 23, 150-156; v) Z. Chen, W. Mori, X. Zhang, T. Yamasaki, P. J. Dunn, G. Zhang, H. Fu, T. Shao, Y. Zhang, A. Hatori, L. Ma, M. Fujinaga, L. Xie, X. Deng, H. Li, Q. Yu, J. Rong, L. Josephson, J.-A. Ma Y. Shao, S. Tomita, M.-R. Zhang, S. H. Liang, Eur. J. Med. Chem. 2018 157, 898-908

[7] a) D. Roeda, F. Hinnen, F. Dolle, J. Labelled Compd. Radiopharm. 2003 46, 1141-1149; b) W. R. Banks, T. J. Tewson, G. A. Digenis, Appl. Radiat Isot. 1990, 41, 719-725; c) U. Heiser, D. Ramsbeck, H.-U. Demuth (Probiodrug AG, Germany), US20120301398A1, 2012 [Chem. Abstr. 158:1161]; d) M. Schou, C. Halldin, J. Labelled Compd. Radiopharm. 2012, 55, 460-462

[8] a) R. Neelamegam, T. Hellenbrand, F. A. Schroeder, C. Wang, J. M. Hooker, J. Med. Chem. 2014, 57, 1488-1494; b) D. Roeda, H. T. Sipila, Y. Bramoulle, J. D. Enas, F. Vaufrey, F. Dolle, C. Crouzel, J. Labelled Compd. Radiopharm. 2002, 45, 37-47; c) M. W. Nader, S. K. Zeisler, A Theobald, F. Oberdorfer, Appl. Radiat. Isot. 1998, 49, 1599-1603; d) M. Van Der Mey, A. D. Windhorst, R. P. Klok, J. D. M. Herscheid, L. E Kennis, F. Bischoff, M. Bakker, X. Langlois, L. Heylen, M. Jurzak, J. E. Leysen, Bioorg. Med. Chem. 2006, 14, 4526-4534; e) M. Hanyu, Y Takada, H. Hashimoto, K. Kawamura, M.-R. Zhang, T. Fukumura, J. Pept. Sci. 2013, 19, 663-668; f) M. Saeed, T. J. Tewson, C. E. Erdahl, A Kohen, Nucl. Med. Biol. 2012, 39, 697-701; g) J. M. Hooker, M Schoenberger, H. Shchieferstein, J. S. Fowler, Angew. Chem. Int. Ed. 2008, 47, 5989-5992; h) G. Berger, M. Maziere, J. Sastre, D. Comar, J. Labelled Compd. Radiopharm. 1980, 17, 59-71; i) D. Roeda, F. Dollé, C Crouzel, J. Labelled Compd. Radiopharm. 1997, 40, 725-726; j) E. H. Abraham (USA ), WO2003099342A1, 2003 [Chem. Abstr. 140:2418]; k) W. B. Mathews, Y. Nakamoto, E. H. Abraham, U. Scheffel, J. Hilton, H. T. Ravert, M. Tatsumi, P. A. Rauseo, B. J. Traughber, A. Y. Salikhova R. F. Dannals, R. L. Wahl, Mol. Imaging Biol. 2005, 7, 203-208.

[9] a) M. Ponchant, F. Hinnen, S. Demphel, C. Crouzel, Appl. Radiat. Isot. 1997, 48, 755-762; b) S. J. Lee, J. S. Fowler, D. Alexoff, M. Schueller, D. Kim, A. Nauth, C. Weber, S. W. Kim, J. M. Hooker, L. Ma, W. Qu, Org Biomol. Chem. 2015, 13, 11235-11243; c) P. S. Kruijer, P. J. Van Leuffen, J. D. M. Herscheid, Appl. Radiat. Isot. 1996, 47, 611-616.

[10] T. Haywood, S. Cesarec, S. Kealey, C. Plisson, P. W. Miller, MedChemComm 2018, 9, 1311-1314

[11] T. Haywood, S. Kealey, S. Sanchez-Cabezas, J. J. Hall, L. Allott, G. Smith, C. Plisson, P. W. Miller, Chem. Eur. J. 2015, 21, 9034-9038.
[12] a) T. Kihlberg, F. Karimi, B. Langstrom, J. Org. Chem. 2002, 67, 3687 3692; b) F. Karimi, T. Kihlberg, B. Langstrom, J. Chem. Soc., Perkin Trans. 1 2001, 1528-1531; c) O. Lindhe, P. Almqvist, M. Kaagedal, S.-A. Gustafsson, M. Bergstroem, D. Nilsson, G. Antoni, Int. J. Mol. Imaging 2011, 694179, 694176 pp; d) S. Kealey, C. Plisson, T. L. Collier, N. J. Long, S. M. Husbands, L. Martarello, A. D. Gee, Org. Biomol. Chem 2011, 9, 3313-3319; e) M. W. Nader, F. Oberdorfer, Tetrahedron Lett 2011, 52, 2309-2311; f) J. Verbeek, J. Eriksson, S. Syvaenen, M. Labots E. C. M. De Lange, R. A. Voskuyl, M. P. J. Mooijer, M. Rongen, A. A Lammertsma, A. D. Windhorst, EJNMMI Res. 2012, 2, 36, 11 pp; g) S Kealey, S. M. Husbands, I. Bennacef, A. D. Gee, J. Passchier, J. Labelled Compd. Radiopharm. 2014, 57, 202-208; h) T. Cornilleau, H. Audrain, A. Guillemet, P. Hermange, E. Fouquet, Org. Lett. 2015, 17 354-357.

[13] a) N. Vasdev, O. Sadovski, A. Garcia, F. Dolle, J. H. Meyer, S. Houle, A A. Wilson, J. Labelled Compd. Radiopharm. 2011, 54, 678-680; b) A Schirbel, M. H. Holschbach, H. H. Coenen, J. Labelled Compd. Radiopharm. 1999, 42, 537-551.

[14] A. Del Vecchio, F. Caille, A. Chevalier, O. Loreau, K. Horkka, C. Halldin M. Schou, N. Camus, P. Kessler, B. Kuhnast, F. Taran, D. Audisio, Angew. Chem., Int. Ed. 2018, 57, 9744-9748.

[15] F. Liger, T. Eijsbouts, F. Cadarossanesaib, C. Tourvieille, D. Le Bars, T. Billard, Eur. J. Org. Chem. 2015, 6434-6438.

[16] a) O. Jacquet, C. Das Neves Gomes, M. Ephritikhine, T. Cantat ChemCatChem 2013, 5, 117-120; b) X. Gao, B. Yu, Z. Yang, Y. Zhao, H Zhang, L. Hao, B. Han, Z. Liu, ACS Catal. 2015, 5, 6648-6652.

[17] a) Y. Bansal, O. Silakari, Biorg. Med. Chem. 2012, 20, 6208-6236; b) R. S. Keri, A. Hiremathad, S. Budagumpi, B. M. Nagaraja, Chem. Biol. Drug Des. 2015, 86, 19-65.

[18] a) R. S. Keri, M. R. Patil, S. A. Patil, S. Budagumpi, Eur. J. Med. Chem 2015, 89, 207-251; b) S. Tariq, P. Kamboj, M. Amir, Arch. Pharm. 2019 352, 1800170.

[19] a) J. P. Holland, S. H. Liang, B. H. Rotstein, T. L. Collier, N. A Stephenson, I. Greguric, N. Vasdev, J. Labelled Compd. Radiopharm. 2014, 57, 323-331; b) N. S. Mason, C. A. Mathis, W. E. Klunk, J. Labelled Compd. Radiopharm. 2013, 56, 89-95.

[20] A. Brayfield, Martindale: The Complete Drug Reference, Pharmaceutical Press, London, UK, 2014. 